Mycologia, 103(2), 2011, pp. 351-360. DOI: 10.3852/10-058

(C) 2011 by The Mycological Society of America, Lawrence, KS 66044-8897

\title{
Phytophthora pini Leonian resurrected to distinct species status
}

\author{
Chuanxue Hong ${ }^{1}$ \\ Virginia Polytechnic Institute and State University, \\ Virginia Beach, Virginia 23455 \\ Mannon E. Gallegly \\ West Virginia University, Morgantown, West Virginia \\ 26506 \\ Patricia A. Richardson \\ Ping Kong \\ Virginia Polytechnic Institute and State University, \\ Virginia Beach, Virginia 23455
}

\begin{abstract}
Phytophthora pini was named by Leonian in 1925, but this species was largely ignored until 1956 and then merged with $P$. citricola by Waterhouse in 1963. This study compared the ex-type and exauthentic cultures of these two species with isolates of $P$. plurivora and the P. citricola subgroups Cil I and III reported previously. Examination of these isolates revealed that the ex-type culture of $P$. pini is identical to P. citricola I. Phytophthora pini Leonian therefore is resurrected to distinct species status and redescribed here with a Latin description, replacing $P$. citricola $\mathrm{I}$. Molecular, physiological and morphological descriptions of this species are presented. The molecular description includes DNA sequences of five nuclear and mitochondrial regions as well as PCR-SSCP fingerprints. The relationship among the above species and other species recently segregated from the $P$. citricola complex also is discussed.
\end{abstract}

Key words: identification, Oomycete, Phytophthora, taxonomy

\section{INTRODUCTION}

L.H. Leonian described Phytophthora pini as a new species in 1925 without a Latin description (Leonian 1925). His one culture was isolated by R.G. Pierce from the roots of red pine (Pinus resinosa Aiton) in Minnesota, USA. Leonian's new species essentially was ignored until 1956 when Grace Waterhouse presented the description in her compilations of original descriptions of species of Phytophthora (Waterhouse 1956). Two years after description of $P$. pini the species $P$. citricola was named by K. Sawada (Sawada 1927); a Latin description was given in 1935 (Ito and Tokunaga 1935). Waterhouse considered the

Submitted 7 Mar 2010; accepted for publication 24 Aug 2010.

${ }^{1}$ Corresponding author. Phone: 757-363-3908; Fax: 757-363-3950; E-mail: chhong2@vt.edu above two species to be the same, with $P$. citricola as the preferred species name (Waterhouse 1963). She also considered P. cactorum var. applanata (Chester 1932) to be the same as P. citricola (Waterhouse 1957).

Subsequent to publication of Waterhouse's key, homothallic isolates with paragynous antheridia, noncaducous semipapillate sporangia and growth temperature maxima of about $30 \mathrm{C}$ were identified as $P$. citricola. However the advent and use of molecular techniques in species identification have revealed that $P$. citricola is a genetically diverse species complex. For instance isozyme analysis of 125 isolates identified 10 electrophoretic types in five distinct groups (Oudemans et al. 1994). Amplified fragment length polymorphism (AFLP) analysis of 86 isolates similarly found four distinct groups (Bhat and Browne 2007). Among 10 isolates considered to be $P$. citricola single-strand conformation polymorphism (SSCP) analysis of PCR-amplified ribosomal DNA internal transcribed spacer (ITS) 1 also revealed four different fingerprints (Cil I-IV) (Kong et al. 2003). Cil IV later was found to produce papillate sporangia and was excluded from the $P$. citricola complex in a key to Phytophthora species (Gallegly and Hong 2008). The fingerprint group designated Cil II is described as $P$. plurivora (Jung and Burgess 2009), and Cil III still awaits description (Hong et al. unpubl data). Other new species descriptions within the citricola complex include $P$. multivora (Scott et al. 2009) and $P$. mengei (Hong et al. 2009a). This paper describes Cil I as $P$. pini. The objective of this paper was to resurrect Phytophthora pini to distinct species status and demonstrate its relationship to closely related taxa.

\section{MATERIALS AND METHODS}

Species and isolates.-Eighty-four isolates including the extype cultures of $P$. citricola, $P$. pini and $P$. c . var. applanata were examined (Table I, Supplemental tables I, II). To avoid confusion in the terminology with different groups of $P$. citricola the type and authentic isolates hereafter are referred to as $P$. citricola s.s. (= sensu stricto), $P$. citricola $\mathrm{I}$, II and IV to as $P$. pini, $P$. plurivora and $P$. quercetorum respectively, unless otherwise followed by a citation of original paper. In the broadest sense as defined by Waterhouse this species complex is referred to as P. citricola sl (= sensu lato). A dried culture of the ex-type $P$. pini is deposited at the Massey Herbarium of Virginia Polytechnic Institute and State University in Blacksburg, Virginia (VTMH: 11737). 


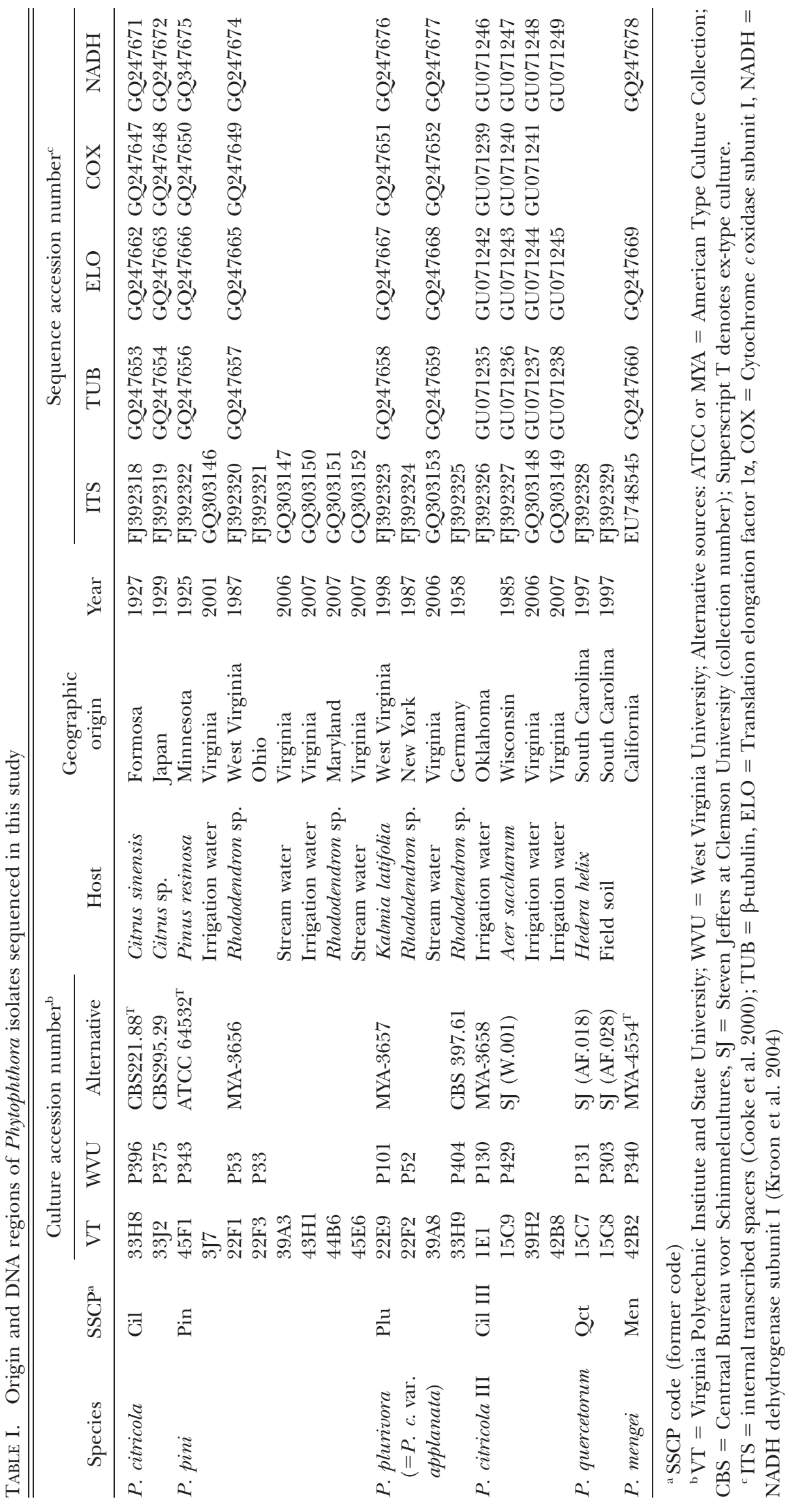


TABLE II. Comparative summary of points of mutation and indels in the five nuclear and mitochondrial DNA regions between $P$. pini and its close relatives

\begin{tabular}{|c|c|c|c|c|c|}
\hline & \multicolumn{3}{|c|}{ Nuclear } & \multicolumn{2}{|c|}{ Mitochondrial } \\
\hline & $\beta$-tubulin ${ }^{\mathrm{a}}$ & $\mathrm{EF}-1 \alpha^{\mathrm{a}}$ & ITS $^{\mathrm{b}}$ & $\operatorname{Cox}^{\mathrm{a}}$ & $\mathrm{NADH}^{\circ}$ \\
\hline Fragment length (bp) & 932 & 903 & 761 & 898 & 829 \\
\hline Total points of mutation and indels & 6 & 15 & 7 & 32 & 16 \\
\hline P. pini vs. $P$. citricola s.s. & $4-5$ & $6-10$ & $4-5$ & $16-17$ & 10 \\
\hline P. pini vs. $P$. citricola III & 1 & 6 & $1-2$ & $3-10$ & 2 \\
\hline$P$. pini vs. P. plurivora & $4-5$ & $6-10$ & $5-6$ & $13-14$ & 9 \\
\hline
\end{tabular}

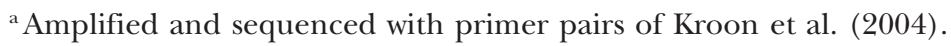

${ }^{\mathrm{b}}$ Amplified and sequenced with primer pair of ITS6 and 4 according to Cooke et al. (2000)

DNA extraction.-Individual isolates were grown in V8 broth (Erwin and Ribeiro 1996) at room temperature (ca. 23 C) $10 \mathrm{~d}$. Genomic DNA was extracted as instructed with the DNeasy ${ }^{\circledR}$ Plant Mini Kit (QIAGEN, Valencia, California).

DNA sequencing and sequence analysis.-One to four isolates of each species (TABLE I) were sequenced in the ribosomal DNA ITS region (Cooke et al. 2000) and genes encoding $\beta$-tubulin (tubulin), translation elongation factor $1 \alpha(e f-1 \alpha), \mathrm{NADH}$ dehydrogenase subunit I (nadh) and cytochrome oxidase subunit I ( $\operatorname{cox} 1)$ (Kroon et al. 2004). Six additional isolates of $P$. pini and two additional isolates of $P$. plurivora and two isolates of $P$. quercetorum also were sequenced in the ITS regions. Each isolate and DNA region was sequenced in both directions at least twice. Consensus sequences were compared to determine intra- and interspecific variations. They also were compared with those deposited in the GenBank with BLASTn at http://ncbi.nlm. nih.gov to determine their phylogenetic position and close relatives. The phylogenic analyses were carried out with MrBayes 3 (Ronquist and Huelsenbeck 2003) in TOPALI 2.5 (Milne et al. 2009). A total of up to 23 other species of Phytophthora representing major clades (Cooke et al. 2000, Martin and Tooley 2003, Kroon et al. 2004, Blair et al. 2008) were selected based on the availability of type culture sequence.

DNA fingerprinting.- - Representative isolates from 25 species (TABle I, Supplemental TABle II) were fingerprinted following a standard procedure (Gallegly and Hong 2008). This procedure is based on PCR-SSCP of rDNA ITS1 (Kong et al. 2003). The only modification was that a smaller volume $(2 \mu \mathrm{L})$ of denatured PCR product was loaded for electrophoresis.

Physiology.-Two isolates each of $P$. citricola s.s., P. pini and $P$. plurivora were selected for temperature experiments. Agar disks (4 mm diam) were taken from actively growing areas of $5 \mathrm{~d}$ old cultures with a flamed cork borer and transferred to freshly prepared V8 agar in $10 \mathrm{~cm}$ diam Petri dishes, one disk placed with the mycelium facing down in the center of each dish. These dishes then were placed in incubators of different settings (5-35 C) in the dark. Three dishes per isolate per temperature were used. Two measurements of colony diameter were taken 2 and $6 \mathrm{~d}$ after onset of tests. The test was repeated once. Average daily radial growth rates of individual isolates were computed and compared by temperature with statistical analysis software V8e (SAS Institute, Cary, North Carolina).

Morphological examination.-Two isolates of $P$. citricola s.s. and 36 of $P$. pini were grown on clarified V8 agar at room temperature $(23$ C) $2 \mathrm{wk}$. Sexual structures then were examined with an Olympus IX71 inverted microscope (Olympus, Center Valley, Pennsylvania). Sporangia were induced by submerging the agar culture blocks in $10 \%$ sterile soil water extract (Erwin and Ribeiro 1996) and incubated at room temperature overnight. Morphological structures were photographed then measured with ImagePro Plus 5.1 (Media Cybernetics Inc., Bethesda, Maryland). Mean and standard error of at least 30 measurements were calculated for each character and isolate, followed by analyses of variance to determine the difference between isolates of the same species and among the species examined. Measurements of both $P$. citricola s.s. isolates were presented, but only those of four representative isolates of $P$. pini were included in this paper.

One or two isolates from each species also were grown on lima bean and hempseed agars for comparison. These morphological examinations were performed as described by Gallegly and Hong (2008). Specifically sporangia were produced on $4 \mathrm{~mm}$ disks in $10 \%$ soil extract from $3 \mathrm{~d}$ old lima bean agar cultures for measurements and photographs, and the sexual structures were produced with hempseed agar.

\section{RESULTS}

Sequence analysis._-Points of mutations and indels in the five nuclear and mitochondrial DNA regions between $P$. pini and its close relatives are summarized (TABLE II). Comparatively few variations were seen in sequences among isolates of individual species. Specifically both isolates of $P$. citricola s.s. had an identical sequence in each of the five regions as did the isolates of $P$. plurivora. Eight isolates of $P$. pini also had an identical ITS sequence except for the type culture, which has a mutation at 650 nt. No or little intraspecific variation was observed in other DNA regions of $P$. pini and $P$. citricola III. 


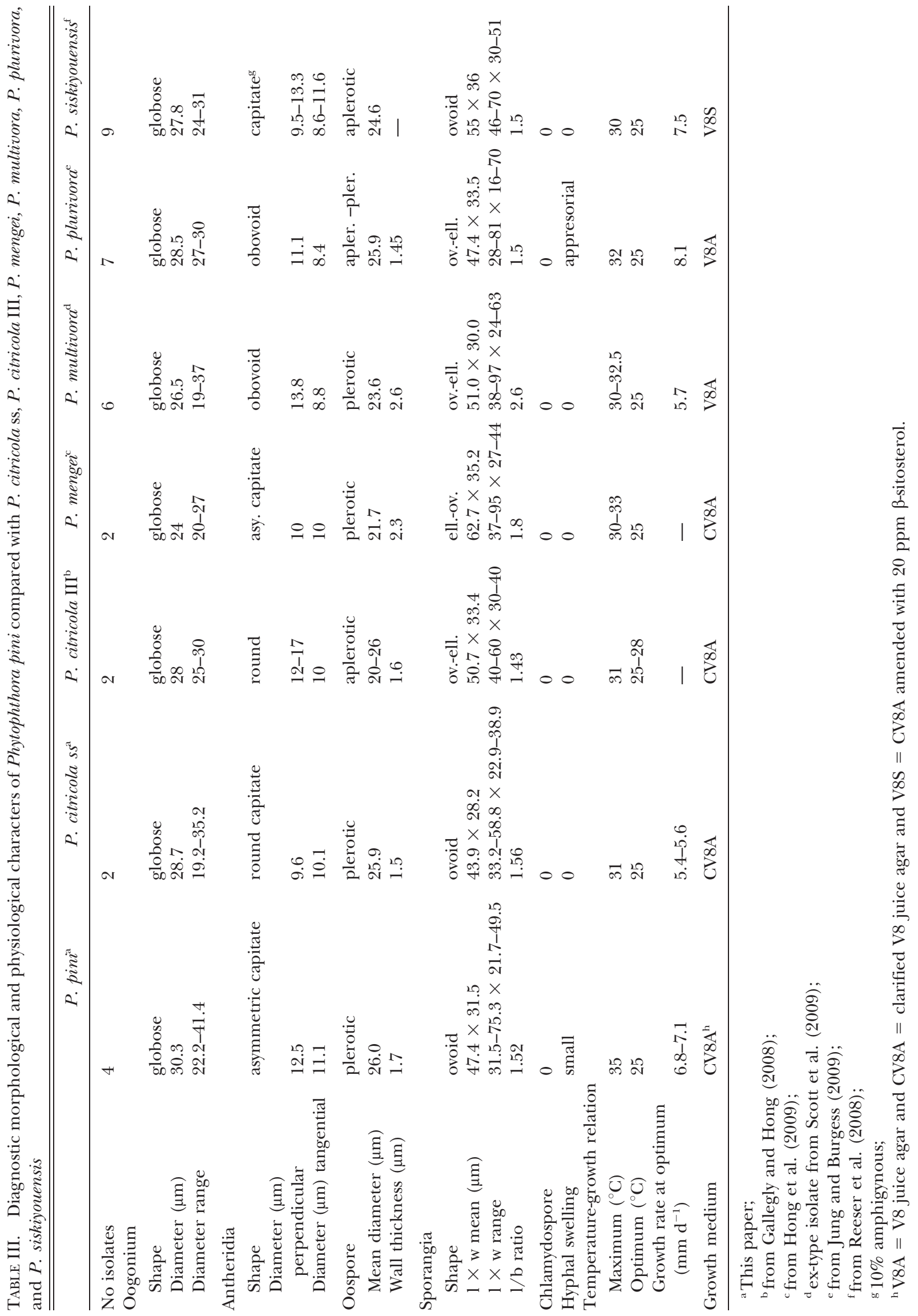


TABle IV. Nomenclature relationship among studies concerning the $P$. citricola sensu lato and ex-type cultures of individual named species and taxa

\begin{tabular}{|c|c|c|c|c|c|}
\hline Present study & $\begin{array}{l}\text { Oudemans } \\
\text { et al. (1994) }\end{array}$ & $\begin{array}{l}\text { Long et al. (2003), } \\
\text { Gallegly and } \\
\text { Hong (2008) }\end{array}$ & $\begin{array}{c}\text { Bhat and } \\
\text { Browne (2007) }\end{array}$ & $\begin{array}{l}\text { Original } \\
\text { reference }\end{array}$ & $\begin{array}{l}\text { Holotype or } \\
\text { representative isolate }\end{array}$ \\
\hline P. citricola $\mathrm{ss}$ & CIT1 (2) & n.a. & n.a. & Sawada (1927) & CBS221.88, IMI021173 \\
\hline P. mengei & CIT5 (9) & n.a. & Avo & Hong et al. (2009) & MYA- 4554 \\
\hline P. multivora & CIT3 (7) & n.a. & n.a. & Scott et al. (2009) & CBS124094 \\
\hline P. pini & CIT1 (2) & P. citricola $\mathrm{I}$ & Mix I and II & Leonian (1925) & $\begin{array}{l}\text { ATCC64532, CBS181.25, } \\
\text { IMI077970 }\end{array}$ \\
\hline $\begin{array}{l}\text { P. plurivora } \\
\quad[=P . c, \text { var. } \\
\text { applanata }]\end{array}$ & $\begin{array}{l}\text { CIT1 }(1) \\
\quad[\text { n.a }]\end{array}$ & $\begin{array}{l}\text { P. citricola } \mathrm{II} \\
\quad[\text { n.a. }]\end{array}$ & $\begin{array}{l}\text { n.a. } \\
\qquad[\text { n.a }]\end{array}$ & $\begin{array}{l}\text { Jung and Burgess (2009) } \\
\quad(\text { Chester [1932]) }\end{array}$ & $\begin{array}{l}\text { CBS124093 } \\
\text { [ATCC 64532, } \\
\text { CBS273.32] }\end{array}$ \\
\hline P. citricola III & n.a. & P. citricola $\mathrm{III}$ & n.a. & Kong et al. (2003) & MYA-3658 \\
\hline P. citricola $\mathrm{E}$ & CIT2 (4) & n.a. & n.a. & Jung and Burgess (2009) & IMI031372 \\
\hline
\end{tabular}

$P$. pini and $P$. citricola III are phylogenetically close. Specifically these two taxa reside in the same terminal cluster of Bayesian inference trees constructed on the ITS (FIG. 1) and $\beta$-tubulin sequences (SUPPLEMENTAL FIG. 1). ITS sequence revealed their closest relatives are $P$. plurivora, $P$. citricola $\mathrm{E}$, followed by $P$. multivora and $P$. citricola s.s., and then by $P$. mengei, $P$. tropicalis, $P$. siskiyouensis and $P$. capsici in the same ITS clade. A similar phylogenetic relationship was observed in the inference tree from the tubulin sequences. However isolates of $P$. pini were consistently grouped in one terminal cluster, whereas those of $P$. citricola III grouped in another cluster in the inference trees from the ef-1 $\alpha$ (SUPPLEMENTAL FIG. 2) and cox 1 sequences (SupPlemental FIG. 3). Both isolates CITUS1 and CIT-US10 placed in P. citricola I (Jung and Burgess 2009) were grouped with Cil III instead of $P$. pini in the $\operatorname{cox} 1$ tree. A similar phylogenetic relationship also was observed in the inference tree constructed on the nadh sequences (SUPPLEMENTAL FIG. 4).

DNA fingerprints.-All 25 species including $P$. citricola s.s., P. pini, P. macrochlamydospora, P. multivesiculata, $P$. bisheria and $P$. siskiyouensis each produced a distinct fingerprint (SUPPLEMENTAL FIG. 5). Both isolates of $P$. citricola s.s. produced an identical DNA fingerprint. Three isolates of $P$. pini also produced an identical fingerprint, as did all other isolates of this species from different hosts and aquatic environments (data not shown). Similarly $P$. cactorum var. applanata produced a fingerprint identical to that of $P$. plurivora (data not shown).

Temperature relations. - Among the six isolates assessed $P$. plurivora and $P$. pini reached the edge of the Petri dishes first after $135 \mathrm{~h}$ at the optimum temperature, 25 C. In comparison the optimum temperature was 20-25 C for $P$. citricola s.s. (SUPPLE-
MENTAL FIG. 6). P. plurivora grew $0.4 \mathrm{~mm}$ per $\mathrm{d}$ at $5 \mathrm{C}$, but $P$. citricola s.s. and $P$. pini did not grow at this temperature. $P$. citricola s.s. and $P$. plurivora grew only during the first $2 \mathrm{~d}$ at $30 \mathrm{C}$, indicating this is their maximum growth temperature. In contrast $P$. pini grew substantially at $30 \mathrm{C}$ throughout the $6 \mathrm{~d}$ period (TABLE III).

\section{TAXONOMY}

Phytophthora pini Leonian, 1925

Emend. Gallegly, Hong, Richardson \& Kong

$=$ Phytophthora citricola I Gallegly \& Hong 2008

Species nova homothallica, antheridiis paragynicis. Oogonia globosa comparate uniformia, numero medio $30.3 \mu \mathrm{m}$ diam (intra 22.2-41.4 $\mu \mathrm{m}$ ). Oosporae maximam partem pleroticae, diametro numerum medium $26.0 \mu \mathrm{m}$ advergente, parietibus cellularum $1.7 \mu \mathrm{m}$ crassis. Antheridia relative magna, capitata vel leviter asymmetrice capitata, diclina, plerumque prope stipitem oogonialem affixa. Interdum antheridia duo per oogonium visa. Mensurae antheridiales numero medio $11.1 \mu \mathrm{m}$ quum tangentiales atque 12.6 um quum perpendiculatae ad parietem oogonialem. Sporangia non caduca semipapillata plerumque ovoidea, sed formas monstruosas visas. Magnitudo sporangiorum numero medio $47.4 \times 31.5 \mu \mathrm{m}$ (intra 31.5-75.3 $\times$ 21.7-49.5 $\mu \mathrm{m})$. Sympodia simplicia interdum praesentia. Chlamydosporae non visae sed interdum areae hyphales extuberantes paucae parvae atque hyphae irregulares interdum in agaro Phaseoli lunati L. "Lima Bean" dicto visae.

Morphology. - Phytophthora pini is homothallic with paragynous antheridia. Oogonia produced on clarified V8 agar are globose and relatively uniform, averaging $30.3 \mu \mathrm{m}$ diam (range 22.2-41.4 $\mu \mathrm{m}$ diam). Oospores are mostly plerotic and average $26.0 \mu \mathrm{m}$ diam (19.6-34.2 $\mu \mathrm{m}$ diam), their cell walls are $1.7 \mu \mathrm{m}$ thick $(1.4-1.9 \mu \mathrm{m})$. The antheridial characters differ from those of $P$. citricola s.s. The antheridia are larger, capitate to slightly asymmetrically capitate, diclinous, 


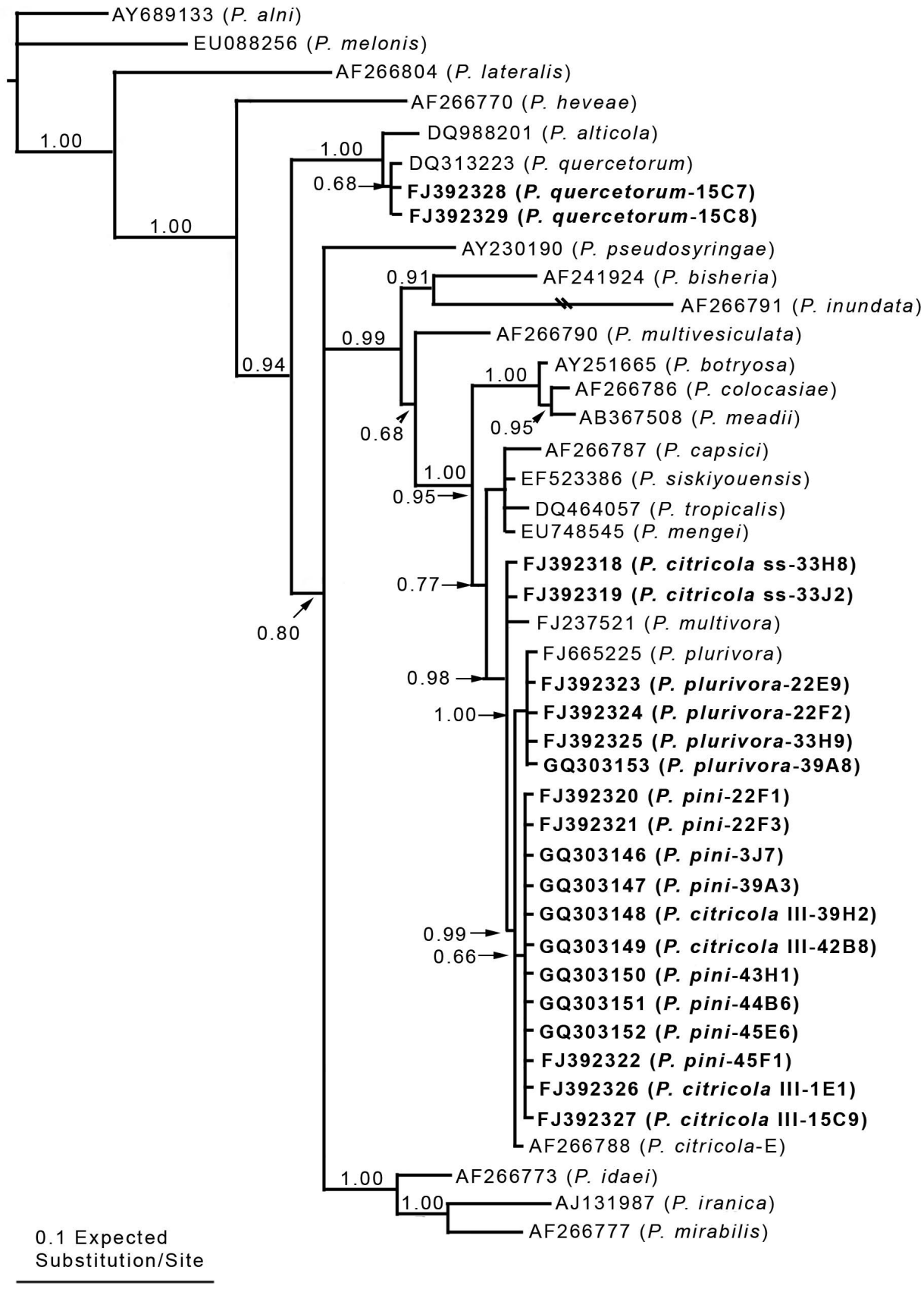

FIG. 1. Bayesian inference tree with rDNA ITS sequences showing the phylogenetic position of Phytophthora pini in relation to other species of Phytophthora. Numbers above branches represent posterior probability based on Bayesian analysis of the dataset. Sequences generated in this study are in boldface.

and attached at the base near the oogonial stalk. Occasionally two antheridia per oogonium may be seen. Antheridia are $11.1 \mu \mathrm{m}$ tangential to the oogonial wall (range 10.2-12.9 $\mu \mathrm{m}$ ) and $12.6 \mu \mathrm{m}$ perpendicular to it $(10.2-15.0 \mu \mathrm{m})$. The noncaducous semipapillate sporangia are mostly ovoid. However ellipsoid, bluntly ellipsoid and bizarre shapes occur in $10 \%$ soil extract. Sporangia averages $47.4 \times 31.5 \mu \mathrm{m}$ $(\mathrm{l} / \mathrm{b}$ ratio is 1.52 and the range is $31.5-75.3 \times 21.7-$
$49.5 \mu \mathrm{m})$. Major character differences were observed among the four isolates assessed (SUPPLEMENTAL TABLE III).

Dimensions of sexual structures produced on hempseed agar average $30.1 \mu \mathrm{m}$ for oogonia, $26.5 \mu \mathrm{m}$ for oospores and $1.7 \mu \mathrm{m}$ for oospore wall. These measurements are comparable to those on clarified V8 agar. Sporangia produced on lima bean agar are $56.8 \mu \mathrm{m}$ long and $36.6 \mu \mathrm{m}$ wide, larger than 

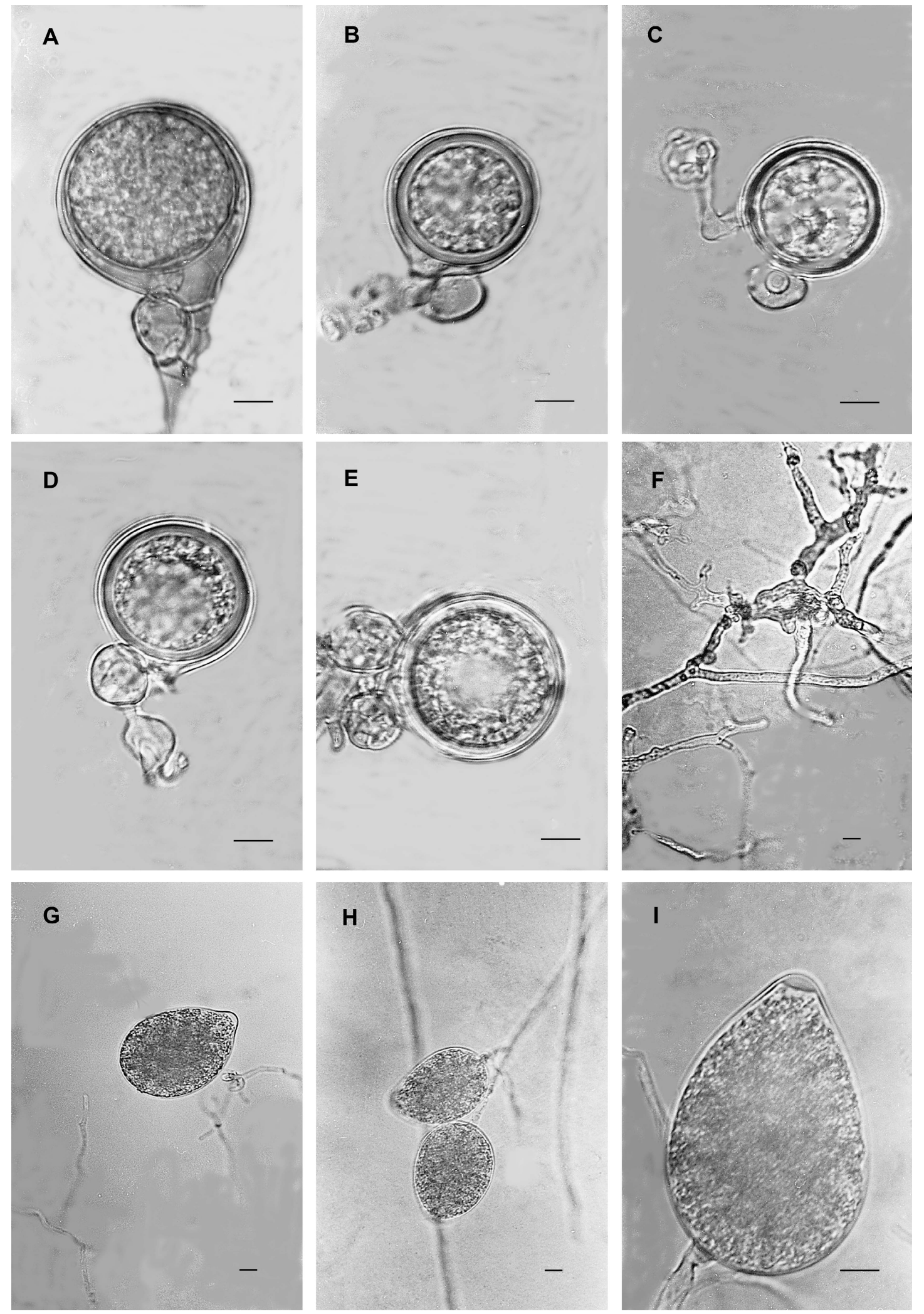

Fig. 2. Phytophthora pini. A. A young sexual stage with a diclinous capitate antheridium and an immature oospore. B, C, D. Sexual stages with mature oospores and the relatively large capitate or asymmetrically capitate antheridia. E. A sexual body with two antheridia. F. Irregular hyphae. G, I. Ovoid sporangia. H. A simple sympodium with two sporangia. 
those on clarified V8 agar. First-flush sporangia are larger and tend toward being ellipsoid, whereas sporangia produced later are smaller and ovoid. Simple sympodia occur, sometimes close but mostly loose. Chlamydospores have not been seen, but a few small hyphal swellings and irregular hyphae sometimes occur in lima bean agar (FIG. 2).

Holotype $=$ VTMH11737 (ATCC 664532, CBS 181.25, IMI 77970)

\section{DISCUSSION}

The results of research (Reeser et al. 2007, Balci et al. 2008, Hong et al. 2009a, Jung and Burgess 2009, Scott et al. 2009) resolved many questions with regard to $P$. citricola s.l. but left pending issues associated with the ex-type cultures of $P$. citricola s.s., $P$. pini and $P$. cactorum var. applanata. This study demonstrates that $P$. pini is a distinct species and by PCR-SSCP fingerprint $P$. cactorum var. applanata belongs to $P$. plurivora (TABLE IV).

Phytophthora pini is resurrected to distinct species status. Phylogenetically $P$. pini is in a terminal cluster different from $P$. citricola s.s. and all other species recently segregated from this species complex. $P$. citricola s.s. and P. pini are similar morphologically. They both have globose oogonia about $30 \mu \mathrm{m}$ diam and plerotic oospores with walls about 1.5-1.7 $\mu \mathrm{m}$ thick. Their antheridia however are different, particularly in size and shape. Those of $P$. pini are larger, $11.1 \mu \mathrm{m}$ tangential to the oogonial wall and $12.6 \mu \mathrm{m}$ perpendicular to the wall, whereas those of $P$. citricola s.s. are round and $10 \mu \mathrm{m}$ or less diam. Also the antheridia of $P$. pini are capitate, usually slightly asymmetrical. In addition $P$. pini formed a few small hyphal swellings and occasional clumps of irregular hyphae, whereas $P$. citricola s.s. did not. Physiologically $P$. pini grew more quickly than $P$. citricola s.s.

Phytophthora citricola I (Kong et al. 2003, Gallegly and Hong 2008) is formally replaced with P. pini because they are phylogenetically, morphologically and physiologically identical. The holotype was deposited by Leonian, and the name $P$. pini should take precedence over other names, although a Latin description was not given and was not required before 1935. Our emended description includes a Latin description of the ex-holotype of ATCC 64532 and CBS 181.25. This isolate is listed under subgroup CIT1 (2) (Oudemans et al. 1994). It must be pointed out that isolates CIT-US1 and CIT-US10 are more closely related to $P$. citricola III than $P$. pini $(=P$. citricola I) in the $\operatorname{cox} 1$ tree, although both were placed in the same group by the ITS sequences (Jung and Burgess 2009). Several differences in temperature response was observed between $P$. pini in the present study and both isolates (CIT-US1 and CIT-US10) (Jung and Burgess 2009): (i) the optimum temperature of $25 \mathrm{C}$ vs. $30 \mathrm{C}$ and (ii) average daily radial growth rates of 7.0 vs. $9.2 \mathrm{~mm}$. These differences along with others (Hong et al. unpubl data) support P. citricola III as a separate taxa (Gallegly and Hong 2008).

Phytophthora pini is readily established in North America and Europe as a pathogen on plants in seven genera. This species also could attack a variety of other ornamental and vegetable plants (Hong et al. 2008) and European beech trees (Jung et al. 2005). It is likely that many isolates identified as P. citricola s.l. in major culture collections in reality are $P$. pini or $P$. plurivora. Similarly many plant species currently listed as hosts of $P$. citricola s.l. (Farr et al. 2009) might be hosts of P. pini instead. Much work will be needed to elucidate the host ranges of $P$. pini and other emerging entities from $P$. citricola s.l.

Phytophthora pini poses a growing threat to the horticulture industry for several reasons. $P$. pini favors alkaline aquatic environments with the optimum $\mathrm{pH}$ of 9 (Kong et al. 2009). This occurs in most agricultural runoff containment basins/irrigation reservoirs for most of the growing season (Hong et al. 2009b). This species consequently has been recovered frequently from irrigation reservoirs and natural waterways in Virginia; some isolates of which were identified as $P$. citricola s.l. or P. citricola I (Bush et al. 2003, Bush et al. 2006, Ghimire et al. 2009). Considering global water scarcity, the horticulture industry increasingly depends on recycled water for irrigation (Hong and Moorman 2005). Accordingly the risk of this species accumulating and being redistributed through recycling irrigation systems is expected to rise. In addition $P$. pini was the only species among the 18 isolates from 12 species tested that can establish itself in media without soil (Hong et al. 2008). Thus it is important to monitor this species closely and take it into consideration in crop health management planning. To this end this study will help put vital research on the right track (Grovers 2001) and improve the accuracy of plant disease diagnostic services.

\section{ACKNOWLEDGMENTS}

This research was supported in part by a grant from USDA/ CSREES/Risk Avoidance and Mitigation Program (200551101-02337). Also Emeritus Professor Gallegly thanks West Virginia University for providing facilities for this study. The authors gratefully acknowledge the supplies of cultures from many colleagues which added much to this study. We also thank Dr Patricia M. Eckel for her assistance in preparing the Latin diagnosis of $P$. pini. 


\section{LITERATURE CITED}

Balci Y, Balci S, Blair JE, Park SY, Kang SC, MacDonald WL. 2008. Phytophthora quercetorum sp nov., a novel species isolated from eastern and north-central USA oak forest soils. Mycol Res 112:906-916, doi:10.1016/j.mycres. 2008.02.008

Bhat RG, Browne GT. 2007. Genetic diversity in populations of Phytophthora citricola associated with horticultural crops in California. Plant Dis 91:1556-1563, doi:10. 1094/PDIS-91-12-1556

Blair JE, Coffey MD, Park SY, Geiser DM, Kang S. 2008. A multilocus phylogeny for Phytophthora utilizing markers derived from complete genome sequences. Fungal Genet Biol 45:266-277, doi:10.1016/j.fgb.2007.10.010

Bush EA, Hong CX, Stromberg EL. 2003. Fluctuations of Phytophthora and Pythium spp. in components of a recycling irrigation system. Plant Dis 87:1500-1506, doi:10.1094/PDIS.2003.87.12.1500

— Stromberg EL, Hong CX, Richardson PA, Kong P. 2006. Illustration of key morphological characteristics of Phytophthora species identified in Virginia nursery irrigation water. Plant Health Prog. doi:10.1094/ PHP-2006-0621-01-RS.

Chester KS. 1932. A comparative study of three Phytophthora diseases of lilac and of their pathogens. J Arnold Arbor 13:232-269.

Cooke DEL, Drenth A, Duncan JM, Wagels G, Brasier CM. 2000. A molecular phylogeny of Phytophthora and related oomycetes. Fungal Genet Biol 30:17-32, doi:10.1006/fgbi.2000.1202

Erwin DC, Ribeiro OK. 1996. Phytophthora diseases worldwide. St Paul, Minnesota: APS Press. 562 p.

Farr DF, Rossman AY, Palm ME, McCray EB. 2009. Fungal databases at http://nt.ars-grin.gov/fungaldatabases/

Gallegly ME, Hong CX. 2008. Phytophthora: Identifying species by morphology and DNA fingerprints. St Paul, Minnesota: APS Press. 158 p.

Ghimire SR, Richardson PA, Moorman GW, Lea-Cox JD, Ross DS, Hong CX. 2009. An in-situ baiting bioassay for detecting Phytophthora species in irrigation runoff containment basins. Plant Pathol 58:577-583, doi:10. 1111/j.1365-3059.2008.02016.x

Grovers F. 2001. Misclassification of pest as 'fungus' puts vital research on wrong track. Nature 411:633, doi: $10.1038 / 35079764$

Hong CX, Gallegly ME, Browne GT, Bhat R, Richardson PA, Kong P. 2009a. The avocado subgroup of Phytophthora citricola constitutes a distinct species, Phytophthora mengei sp. nov. Mycologia 90:833-840.

— Lea-Cox JD, Ross DS, Moorman GW, Richardson PA, Ghimire SR, Kong P. 2009b. Containment basin water quality fluctuation and implications for crop health management. Irrigation Sci 29:485-496, doi: 10.1007/s00271-009-0161-4

—, Moorman GW. 2005. Plant pathogens in irrigation water: challenges and opportunities. Crit Rev Plant Sci 24:189-208, doi:10.1080/07352680591005838

—, Richardson PA, Kong P. 2008. Pathogenicity to ornamental plants of some existing species and new taxa of Phytophthora from irrigation water. Plant Dis 92: 1201-1207, doi:10.1094/PDIS-92-8-1201

Ito S, Tokunaga Y. 1935. Notae mycologicae Asiae orientalis I. (Mycolgoical notes from eastern Asia). Trans Sappoor Nat Hist Soc 14:11-33.

Jung T, Burgess TI. 2009. Re-evaluation of Phytophthora citricola isolates from multiple woody hosts in Europe and North America reveals a new species, Phytophthora plurivora sp. nov. Persoonia 22:95-110.

-_- Hudler GW, Jensen-Tracy SL, Griffiths HM, Fleischmann F, Osswald W. 2005. Involvement of Phytophthora species in the decline of European beech in Europe and the USA. Mycologist 19:159-166, doi:10.1017/S0269915X05004052

Kong P, Hong CX, Richardson PA, Gallegly ME. 2003. Single-strand-conformation polymorphism of ribosomal DNA for rapid species differentiation in genus Phytophthora. Fungal Genet Biol 39:238-249, doi: 10.1016/S1087-1845(03)00052-5

_ Moorman GW, Lea-Cox JD, Ross DS, Richardson PA, Hong CX. 2009. Zoosporic tolerance to $\mathrm{pH}$ stress and its implications for Phytophthora species in aquatic ecosystems. Appl Environ Microbiol 75:4307-4314, doi:10.1128/AEM.00119-09

Kroon L, Bakker FT, van den Bosch GBM, Bonants PJM, Flier WG. 2004. Phylogenetic analysis of Phytophthora species based on mitochondrial and nuclear DNA sequences. Fungal Genet Biol 41:766-782, doi:10. 1016/j.fgb.2004.03.007

Leonian LH. 1925. Physiological studies on the genus Phytophthora. Am J Bot 12:444-498, doi:10.2307/2435501

Martin FN, Tooley PW. 2003. Phylogenetic relationships among Phytophthora species inferred from sequence analysis of mitochondrially encoded cytochrome oxidase I and II genes. Mycologia 95:269-284, doi:10. $2307 / 3762038$

Milne I, Lindner D, Bayer M, Husmeier D, McGuire G, Marshall DF, Wright F. 2009. TOPALI v2: a rich graphic interface for evolutionary analyses of multiple alignments on HPC clusters and multi-core desktops. Bioinformatics 25:126-127, doi:10.1093/bioinformatics/btn575

Oudemans P, Forster H, Coffey MD. 1994. Evidence for distinct isozyme subgroups within Phytophthora citricola and close relationships with $P$. capsici and $P$. citrophthora. Mycol Res 98:189-199, doi:10.1016/ S0953-7562(09) 80185-8

Reeser PW, Hansen EM, Sutton W. 2007. Phytophthora siskiyouensis, a new species from soil, water, myrtlewood (Umbellularia californica) and tanoak (Lithocarpus desiflorus) in southwestern Oregon. Mycologia 99: 639-643, doi:10.3852/mycologia.99.5.639

Ronquist F, Huelsenbeck JP. 2003. MrBayes 3: Bayesian phylogentic inference under mixed models. Bioinformatics 19:1572-1574, doi:10.1093/bioinformatics/ btg 180

Sawada K. 1927. Descriptive catalogue of the formosan fungi III. Rep. Dept. Agric. Res. Inst. Formosa. 27, 73 p. (in Japanese) (cited by Tucker 1931).

Scott PM, Burgess TI, Barber PA, Shearer BL, Stukely MJC, Hardy GESJ, Jung T. 2009. Phytophthora multivora sp. 
nov., a new species recovered from declining Eucalyptus, Banksia, Agonis and other plant species in Western Australia. Persoonia 22:1-13.

Waterhouse GM. 1956. The genus Phytophthora: diagnoses (or description) and figures from the original papers. Kew, Surrey: Commonw. Mycol. Inst.
- 1957. Phytophthora citricola Sawada (syn. P. cactorum var. applanata Chester). Trans Br Mycol Soc 40:349357, doi:10.1016/S0007-1536(57)80031-X

. 1963. Key to the Species of Phytophthora de Bary. Mycological Paper 92. Surrey, England: Commonw. Mycol. Inst. 